\title{
The efficiency of some bioagent fungi in reduction of wheat seed decay and seedling damping-off disease with heavy metals interaction
}

\author{
QUSAI HATTAB MADHI`, MOHAMMED HAMZA ABASS, ABDULNABI ABDUL AMEER MATROOD \\ Department of Plant Protection, College of Agriculture, University of Basrah. Basrah, Iraq \\ vemail: qusaihattab82@yahoo.com
}

Manuscript received: 17 May 2021. Revision accepted: 28 August 2021.

\begin{abstract}
Madhi QH, Abass MH, Matrood AAA. 2021. The efficiency of some bioagent fungi in reduction of wheat seed decay and seedling damping-off disease with heavy metals interaction. Biodiversitas 22: 3984-3993. Biological control is an ecofriendly efficient measurement for disease control and heavy metals reduction in soils. The use of bioagent fungi such as Trichoderma koningii and Chaetomum globosum reduced the negative effect of pathogenic fungi that cause seed decay and the seedlings damping off wheat alone or by interaction with the concentrations of lead or cadmium, which increases the germination percentage of wheat seeds and reducing seedling damping off. It also reduced the severity index of wheat with pathogenic fungi and reduced the negative effect of interaction between heavy metals and pathogenic fungi on the severity index of the wheat. Results showed that T. koningii and $C$. globosum reduced the effect of the interaction of $R$. solani with $200 \mathrm{mg} / \mathrm{kg}$ lead to 57.7 and $55.4 \%$, respectively and $R$. solani and cadmium 3 $\mathrm{mg} / \mathrm{kg}$ with 60 and $61.6 \%$, respectively. T. koningii and C. globosum also reduced the effect of the interaction F.solani with lead 200 $\mathrm{mg} / \mathrm{kg}$ to 45.4 and $48.5 \%$, respectively and $F$. solani and cadmium $3 \mathrm{mg} / \mathrm{kg}$ to 46.8 and $52.5 \%$ respectively. The bioagent fungi also increased the fresh and dry weight of shoot and root system, T. koningii significantly increased the fresh and dry weight of shoot in the presence of $R$. solani. The results also indicated that there was a high significant difference in the use of $C$. globosum in increasing the fresh and dry weight of shoot and root system. T. koningii and C. globosum significantly reduced the effect of interaction between the pathogenic fungi and low concentrations of lead and cadmium leading to an increase in the fresh and dry weight of shoot and root system. They also increased the plant height in the presence of pathogenic fungi as well as reducing the negative effect of the interaction between heavy metals and pathogenic fungi in the height of wheat plants. No significant interaction was observed between the low concentrations of lead and cadmium and pathogenic fungi in the presence of bioagent fungi. The results exhibited that bioagent fungi can reduce the negative effect of interaction of pathogenic fungi with lead and cadmium on the total phenols content of wheat leaves, and no significant difference was recorded in the treatment of low concentrations with the pathogenic fungi. Results showed that bioagent fungi can reduce the negative effect of the interaction of pathogenic fungi with lead and cadmium on the total phenols content of wheat plant leaves. No significant differences were recorded in the treatment of low concentrations with the pathogenic fungi in the presence of bioagent fungi. The two bioagent fungi increased the concentration of chlorophyll a and $b$, total chlorophyll and carotenoids reduced anthocyanin in leaves, and increased chlorophyll stability index compared to the control treatment.
\end{abstract}

Keywords: Damping-off, fungi, heavy metals, pathogenicity, wheat

\section{INTRODUCTION}

Triticum aestivum $\mathrm{L}$. is the universal cereal of the old world agriculture and the world's foremost consumed crop plant after rice and maize (FAOSTAT 2011). This crop is currently cultivated in more than seventy different countries around the world, with approximately 3864.4032 hectares of cultivated areas, with about 3052.939 million tons of harvested grains (FAO 2018), and Iraq is among these countries with a production of 1518471 tons with an area of 633.1116 hectares (CASO 2019). Global cereal production needs a significant increase in production in the coming decades to meet the food and feed consumption needs of humankind. Global production of wheat, corn, rice and soybeans peaked at 2,102 million tons of harvested grains in 2018. Pre-harvest losses due to diseases, animal pests, weeds, abiotic and harvest pressures annually destroy about $35 \%$ of total biological output and lead to direct and indirect impact of pests on production results in heavy losses in grains (Mesterhazy et al. 2020).
Abiotic stress, biological control of plant pests and pathogens, and bio-plant treatment have gained great importance in recent years due to climate change and soil and natural resource pollution that increase crop stress, limiting and reducing production (Bamisile et al. 2018; Nandy et al. 2020). The growth of plants is mainly supported by the microorganisms that live in the soil area near the roots i.e. the rhizosphere, which includes many life forms such as fungi, bacteria and viruses, and also inside the plant, i.e. the endosphere (Manara 2012). The microbes present in the rhizosphere are tolerant of minerals and facilitate plant growth through several mechanisms through the proliferation of root filaments, thus increasing the surface area, and facilitating mineral absorption and directing to the aerial parts of plants (Wu et al. 2009). Pischik et al. (2009) stated that microbes are found in both the endosphere and the rhizosphere, and aid in the absorption, dissolution and tolerance of heavy metals (Zhu et al. 2014). Endophytes are those that can be isolated from healthy plant tissues including beneficial neutral or 
commensal microorganisms, as well as inactive microorganisms and underlying pathogens. It is well known that some endophytes contribute to plant health and aid in plant adaptation. Biotic and abiotic stress conditions (Mani and Natesan 2018). Some endophytic fungi such as Chaetomum globosum are able to reduce the damage caused by plant pathogens by their hostility by excessive parasitism, competition, or production of antibiotics, or by activating plant defenses. Endogenous fungi are able to increase plant tolerance to abiotic stress such as dehydration or salinity or elevation of temperature and heavy metals by activating plant stress responses, allowing plants to avoid or mitigate the effect of stress $(\mathrm{Fu}$ et al. 2007; Siya et al. 2020). Trichoderma sp. is commonly found in roots, soil, and all environmental conditions. It can grow faster and produce strong spores and enzymes that degrade pathogen cell walls. It is an environmentally friendly biological control agent and is characterized by high resistance to various toxins and biotic compounds including antibiotics, fungicides and heavy metals (Harman et al. 2004). It has good produced antibody ability against some fungi that cause plant diseases (Benitez et al. 2004). Kredics et al. (2001) reported that mercury ( $\mathrm{Hg}$ ) does not affect the production of extracellular enzymes of $T$. harzianum. For this reason, it is more effective in the case of heavy metal stress against the fungal pathogens. The aim of the present research is to find out the effect of biological fungi on seed pathogen interference, seed death, lead, and cadmium concentrations.

\section{MATERIALS AND METHODS}

The experiment was carried out in the Laboratories of the Plant Protection Department, and the field experiment was carried out at the Agricultural Research Station of the College of Agriculture - University of Basrah.

\section{Sources of fungal isolates}

The isolates of pathogenic fungi Rhizoctonia solani, Fusarium solani and Macrophomina phaseolina were isolated from the root and soil of wheat plant according to Abass et al. (2021). In addition, the two fungi Trichoderma koningii and Chaetomium globosum were obtained from the Laboratories of the Prevention Department/College of Agriculture/University of Basrah.

\section{Field experiment}

Soil was collected from the Kumet area in the Maysan governorate, and the analysis of lead and cadmium in the soil showed that these minerals did not exceed the permissible standard limits for heavy metals EU (2006) also the concentrations of lead and cadmium were determined based on Madhi et al. (2020). Three concentrations of each element were determined for the study treatments, as cadmium chloride $\mathrm{CdCl}_{2}$ was used as a source of cadmium and lead acetate $\mathrm{Pb}(\mathrm{C} 2 \mathrm{H} 30)_{2}$ as a source of lead, and 200,400, $600 \mathrm{mg} / \mathrm{kg}$ concentrations were used for lead and 3,6 and $10 \mathrm{mg} / \mathrm{kg}$ for cadmium. The sterilized soil was distributed in plastic pots of $5 \mathrm{~kg}$ capacity and in equal quantities. The inoculum of each pathogenic fungi and bioagent fungi was applied on the seeds of local millet (treatment) at a rate of $2 \%$ (weight/weight) (Jones et al. 1984). Then the seeds of wheat cultivar Iba 99 were planted and 10 seeds were sown per pot. Sterile water was used as irrigation water and with equivalent field capacity and the specifications of the water were (pH 7.5 and electrical conductivity 1.3 Desmens $/ \mathrm{m}$ ). No significant concentration of elements were determined in the water samples. Treatments that include the addition of heavy metals were watered at all three concentrations and the experiment lasted for 60 days. The experiment was carried out using a complete randomized designe (CRD) with three replicates per treatment:
1. control
2. R.s+T.gon
3. R.s+C.glob
4. F.s+T.con
5. F.s.+C.glob
6. M.ph+T.con
7. M.ph+C.glob
8. R.s+T.con+ Pb200
9. R.s+T.con+ $\mathrm{Pb} 600$
10. R.s+T.con+ Cd3
11. R.s+T.con+ Cd10
12. R.s+C.glob + Pb200
13. R.s+C.glob $+\mathrm{Pb} 600$
14. R.s+C.glob $+\mathrm{Cd} 3$
15. R.s + C.glob $+\mathrm{Cd} 10$
16. F.s+T.con+ Pb200
17. F.s+T.con+ Pb600
18. F.s+T.con+ Cd3
19. F.s+T.con+ Cd10
21. F.s + C.glob+ $\mathrm{Pb} 600$
22. F.s + C.glob+ $\mathrm{Cd} 3$
23. F.s + C.glob+ Cd10
24. M.ph+T.con+Pb600
25. M.ph+T.con+ Pb200
26. M.ph+T.con $+\mathrm{Cd} 3$
27. M.ph+T.con+ Cd10
28. M.ph+ C.glob+ Pb200
29. M.ph+ C.glob+ Pb600
30. M.ph+ C.glob+ Cd3
31. M.ph+C.glob.+ Cd10

The experiment lasted for sixty days, and after the end of the experiment the following measurements were taken:

The percentage of germination and damping-off :

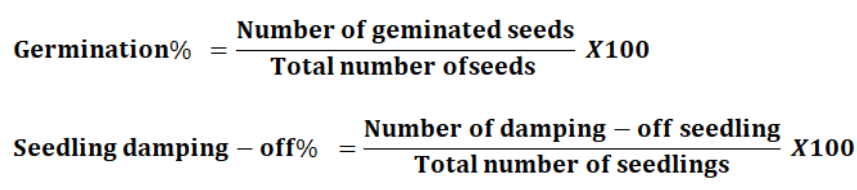

Severity Index: The severity of the infection was calculated according to the scale mentioned by Wheeler (1970) consisting of four degrees as follows: (0) Seedlings are intact, (1) Seedlings are alive but infected with root rot , 
(2) pre-emergence damping off, (3) post-emergence damping off

The severity index was calculated according to the following equation:

Severity Index $\%=\frac{\text { Total of seedling } \times \text { degree }}{\text { Total of seedlings } \times \text { higher degree }} X 100$

Average plant height (cm): The height of the plant was measured by a tape measure from the soil surface to the top of the plant.

Fresh and dry weight of the shoot and root (gm): The fresh weight was calculated by taking three plants for each treatment by cutting the plants at their contact area with the soil then the plants were dried using an electric oven at a degree of $60 \mathrm{~m}$ for 72 hours. Then the dry weight was calculated using the sensitive balance.

Determination of total phenols: Phenol contents was determined in wheat leaves by following the Singleton and Rossi method (1965). Briefly, $200 \mathrm{mg}$ of leaves were weighed and added $2 \mathrm{ml}$ of $50 \%$ methanol and placed in a mechanical shaker at a speed of $200 \mathrm{rpm} /$ minute at room temperature for two hours. Then the filtrate was separated by a centrifugation process at a speed of $10,000 \mathrm{rpm}$ for 15 minutes. The filtrate was kept in a $4 \mathrm{ml}$ vial and the extraction process was repeated with the same previous steps. The second filtrate was mixed with the first filtrate. 200 microliters of filtrate were taken in test tubes after that $1.5 \mathrm{ml}$ of Folin-Ciocalten reagent was added (diluted to ten times with distilled water) and left for five minutes at room temperature, then add $1.2 \mathrm{ml}$ sodium bicarbonate $\mathrm{Na}_{2} \mathrm{CO}_{3}$ $(7.5 \%)$ (weight/volume) and left the mixture for 60 minutes before reading the absorbance along with the length 765 nm. A sample was prepared with the same steps but without adding a filtrate as a control sample. The total amount of phenols was calculated using the standard Gallic acid curve. The results were expressed as equivalent to Gallic acid in $\mathrm{mg} / \mathrm{g}$ fresh weight unit.

Photosynthetic pigments and chlorophyll stability index: Chlorophyll a, chlorophyll b, total chlorophyll, carotenoids and anthocyanin were estimated according to Arnon method (1949). $200 \mathrm{mg}$ of leaves were crushed in 8 $\mathrm{ml}$ of acetone $(80 \%)$ in a chilled ceramic mortar, followed by centrifugation at $3,000 \mathrm{rpm}$ for $30 \mathrm{~min}$. The optical density of chlorophyll-a, chlorophyll-b, carotenoids and anthocyanin were recorded at 645, 663, 534, $470 \mathrm{~nm}$, respectively. Acetone was used as a control sample to calibrate the instrument, use a spectrophotometer model UV-1100D. The pigments were estimated according to the following equations Asare-Boamah et al.(1986) and expressed in $(\mathrm{mg} / \mathrm{g})$.

Chlorophyll $-a=12.7$ (0D663) -2.69 (OD645) x Vol./Wt)

Chlorophyll $-b=22.9$ (OD645) -4.68 (OD663) $\times$ Vol./Wt)

Total chlorophyll $=20.2($ DD 645) $+8.02($ DD 663) $\times$ Vol. $/$ Wt. $)$

Anthocyanins $=0.0821 \times$ A534-0.0439 A643 - 0.002423 $\times$ A661

Carotenoids $=\mathrm{A} 470-17.1 \times(\mathrm{Chl}-a+\mathrm{Chl}-b)-9.479 \times$ anthocyanins $) / 119.26$

\section{Chlorophyll stability index (CSI)}

Chlorophyll stability index was calculated in stress and control plants by following formula (Sairam et al.1997):

CSI $(\%)=$ Total Chlorophyll in control plant/ Total Chlorophyll in stressed plant $\times 100$

\section{RESULTS AND DISCUSSION}

\section{The efficiency of bioagent fungi in reduction of seed fungal pathogens and heavy metals interaction}

The results indicated the significant effect of the bioagent fungi against the pathogenic fungi showing an increase in the percentage of wheat seed germination and a decrease in seedling damping off. The treatment of the bioagent fungus $T$. koningii and the pathogenic fungus $R$. solani recorded germination and seedling damping-off percentage of 73.33 and $27.05 \%$ respectively, and the percentage of germination and seedling damping-off due to treatment of fungus $T$. koningii and $F$. solani were recorded as 76.66 and $23.03 \%$, respectively. The percentage of seed germination increased and damping-off decreased due to the presence of the biological fungus $C$. globosum, and the highest effect was recorded by the pathogen M. phaseolina, as the germination percentage increased to $80 \%$ and the damping-off decreased to $5.93 \%$. There was less biological effect on the pathogen $R$. solani, which was recorded 76.66 and $26.06 \%$, respectively, as compared to the control treatment (Table 1).

The results of Table 1 showed that the bioagent fungi reduced the negative effect of interaction between heavy metals and pathogenic fungi on the percentage of germination and seedling damping-off. $T$. koningii reduced the interaction effect between lead $200 \mathrm{mg} / \mathrm{kg}$ and $R$. solani to 70.00 and $27.06 \%$, respectively, and also reduced the interaction between cadmium $3 \mathrm{mg} / \mathrm{kg}$ and $R$. solani with 66.66 and $25.23 \%$, respectively as compared to the treatment. $C$. globosum reduced the effect of the interaction of $R$. solani and $200 \mathrm{mg} / \mathrm{kg}$ of lead by 73.33 and $27.85 \%$, respectively, and the interaction of $R$. solani and $200 \mathrm{mg} / \mathrm{kg}$ of cadmium reduced it to 70 and $27.05 \%$, respectively, compared with the interaction of biotic fungi and the pathogen without lead or cadmium. The reason for the biological ability of the fungi to increase the germination rate of wheat seed and reduce the seedling damping-off may be attributed to the excretion of Trichoderma sp. Several pathogens secretes cell wall degrading enzymes (CWDE), such as chitinases and $\beta-1,3$-glucanases, also inhibits the formation of sclerotia in $R$. solani (Naeimi et al. 2010). The fungus $C$. globosum produces enzymes such as xylanase and 1,3-glucanase and hydrolytic enzymes. It also produces various metabolites such as chaetomin and chaetoglobosin that have anti-fungal properties (Ahammed et al. 2012). C. globosum produce pectin degrading enzymes polygalacturonate trans-Eliminase (PGTE), pectin trans-eliminase (PTE), polygalacturonase (PG), pectin methylesterase (PME), protopectinase (PP), methylesterase (PME), protopectinase (PP), and protopectinase (PP). Cellulolytic and several bioactive substances such as chaetoglobosin A, Chaetomium B, C, D, Q, R, T, 
chaetocin, chaetomin, chaetochalasin A, and chaetoviridins $\mathrm{A}$ and $\mathrm{C}$ was also produced by $C$. globosum (Ashwini 2019). Pandey et al. (2019) reported that mechanisms that biotic fungi use are antifungal production, specialized antigenicity, and stimulation of plant immunity. It can also be attributed to the role of biotic fungi in analyzing organic and inorganic pollutants in the soil, reducing the toxicity of pollutants to plants, providing a good environment for plant growth and forming a physical barrier around plant roots that protect them from unfavorable environmental conditions and limit the invasion of pathogens and pests (Wu and Lin 2003). Moubarak and Abdel-Monaim (2011) reported that Trichoderma sp. reduced seedling fall and wheat root rot caused by $R$. solani and $F$. solani fungi compared to the control treatment. Abbas et al. (2017) indicated that Trichoderma sp. inhibited the $R$. solani fungus that caused root rot and seedling damping-off pre and post-emergence by having many mechanisms such as parasitism, production of antibiotics and competition in addition to stimulating plant defense responses. Latz et al. (2018) reported that $C$. globosum protects the plant from disease, reduces infection levels, and inhibits pathogen growth.

The results of Table 1 indicated that biotic fungi $T$. koningii and $C$. globosum reduced the severity index of wheat with pathogenic fungi. T. koningii reduced the severity index of $R$. solani, $F$. solani and M. phaseolina to 51.23, 40.8 and 22.05\%, respectively, also C. globosum reduced the severity of infection by $45,42.2$ and $15.3 \%$. The results showed that the biological fungi reduced the negative effect of the interaction between heavy metals and pathogenic fungi on the severity of wheat plant infestation. $T$. koningii and $C$. globosum reduced the effect of $R$. solani interaction with lead $200 \mathrm{mg}$ to 57.7 and $55.4 \%$, respectively, and they also reduced the interaction effect between $R$. solani and cadmium $3 \mathrm{mg} / \mathrm{kg}$ to 60 and $61.6 \%$, respectively, compared with the pathogen and the bioagent fungus without lead or cadmium. The reason for the reduced severity index may be attributed to the role of biotic fungi in protecting plants from pathogens and abiotic stresses such as high concentrations of heavy metals, as well as enhancing plant growth through biosynthesis of plant hormones and nutrients acquisition (Humberto et al. 2020). Azevedo and Araujo (2007) stated that biofungi stimulate plant metabolism changes that alter their response to environmental stress and pathogen attack.

In addition, this interaction leads to the production of secondary metabolites by both fungi and plants, which enhances the ability to respond to environmental stress. Trichoderma sp. it secretes various biological metabolites that are toxic to plant pathogenic fungi such as pyrones, koninginins, viridian, gliovirin, gliotoxin, peptaibols and others (Vinale et al. 2014). C. globosum produces several bioactive compounds such as azaphilones (Yamada et al. 2011) and armochaetoglobins $\mathrm{A}-\mathrm{J}$, which are antifungal, cytotoxic and inhibitory for pathogenic fungi (Chen et al.
2015). Kredics et al. (2001) reported the use of Trichoderma sp. against $R$. solani and Fusarium sp. in soils contaminated with heavy metals, it produced the main active parasitizing enzymes, such as chitinase, protease, or B-1,3 glucanase, which participate in the degradation of fungal cell walls. All strains of Trichoderma sp. showed the best tolerance levels for nickel and manganese. Demirici et al. (2011) reported that Trichoderma sp. produces various enzymes cutinase, cellualse, protease, and B-1,3-gluconase, and produces many antibiotics such as Trichodermin, Pachybas, and Emodin chrysophancol as well as the production of toxic substances such as Gliotoxin that inhibit the bacterium of fungi. The fungus $C$. globosum reduced the severity of wheat plant infestation with Bipolaris sorokiniana by producing many active compounds such as chaetoviridin A, chaetoviridin E, chaetoglobosin $\mathrm{C}$, epichaetoviridin $\mathrm{A}$, epichaetoviridin $\mathrm{T}$ and prochaetoglobosins I (Yue et al. 2018).

Table 1. The efficiency of bioagent fungi in reduction of seed fungal pathogens and heavy metals interaction on wheat seed germination and seedling damping-off

\begin{tabular}{|c|c|c|c|}
\hline \multirow[b]{2}{*}{ Treatments } & \multicolumn{3}{|l|}{ Percentage } \\
\hline & $\begin{array}{l}\text { Germi- } \\
\text { nation }\end{array}$ & $\begin{array}{l}\text { Damping } \\
\text { off }\end{array}$ & $\begin{array}{l}\text { Severity } \\
\text { index }\end{array}$ \\
\hline Control & 100.000 & 0.000 & 00.00 \\
\hline R.S. +T.gon & 73.333 & 270.500 & 51.23 \\
\hline R.S. +T.gon+Pb200 & 70.000 & 270.600 & 57.7 \\
\hline R.S. +T.gon+Pb600 & 63.333 & 292.833 & 64 \\
\hline R.S. +T.gon+Cd3 & 666.667 & 252.333 & 60 \\
\hline R.S. +T.gon+Cd10 & 566.667 & 26.666 & 70.25 \\
\hline R.s.+ C.glob & 766.667 & 260.667 & 45 \\
\hline R.s. + C.glob $+\mathrm{Pb} 200$ & 733.333 & 278.500 & 55.4 \\
\hline R.s. + C.glob+Pb600 & 666.667 & 294.333 & 62.5 \\
\hline R.s. + C.glob+Cd3 & 70.000 & 270.500 & 61.6 \\
\hline R.s. + C.glob+Cd10 & 60.000 & 359.500 & 67.875 \\
\hline F.S. +T.gon & 766.667 & 230.333 & 40.8 \\
\hline F.S. +T.gon+Pb200 & 766.667 & 254.333 & 45.4 \\
\hline F.S. +T.gon+Pb600 & 70.000 & 278.500 & 66 \\
\hline F.S. +T.gon+Cd 3 & 733.333 & 254.333 & 46.8 \\
\hline F.S. +T.gon+Cd10 & 63.333 & 302.333 & 67.00 \\
\hline F.s.+ C.glob & 80.000 & 169.000 & 42.2 \\
\hline F.s. + C.glob $+\mathrm{Pb} 200$ & 80.000 & 254.333 & 48.5 \\
\hline F.s. + C.glob $+\mathrm{Pb} 600$ & 70.000 & 278.500 & 60 \\
\hline F.s. + C.glob+Cd 3 & 76.667 & 246.667 & 52.5 \\
\hline F.s. + C.glob+Cd10 & 666.667 & 302.333 & 63.33 \\
\hline M.ph +T.gon & 80.000 & 5.930 & 22.05 \\
\hline M.ph. +T.gon+Pb200 & 760.000 & 100.000 & 25 \\
\hline M.ph. +T.gon+Pb600 & 70.000 & 15.000 & 51.00 \\
\hline M.ph. +T.gon+Cd3 & 73.333 & 117.833 & 30.11 \\
\hline M.ph +T.gon+Cd10 & 70.000 & 255.333 & 60.5 \\
\hline M.ph.+ C.glob & 83.333 & 111.867 & 15.3 \\
\hline M.ph. + C.glob+Pb200 & 80.000 & 152.333 & 24.4 \\
\hline M.ph + C.glob+Pb600 & 766.667 & 194.333 & 46.8 \\
\hline M.ph. + C.glob+Cd3 & 80.000 & 167.833 & 36.8 \\
\hline M.ph. + C.glob+Cd10 & 70.000 & 219.000 & 57.7 \\
\hline L.S.D & 6.516 & 2.475 & 6.702 \\
\hline
\end{tabular}




\section{The efficiency of bioagent fungi in reduction of seed fungal pathogens and heavy metals interaction on shoot and root growth of wheat plants}

Results showed that bioagent fungi have the ability to increase the fresh and dry weight of the shoot and root system, as T. koningii recorded a significant increase in the fresh and dry weight of the shoot in the presence of $R$. solani, which was 5.792 and $2.790 \mathrm{gm}$, respectively, and a significant increase in the fresh and dry weight of the root system was 2.029 and $0.637 \mathrm{~g}$, respectively (Table 2). The highest significant increase was recorded in the treatment of T. koningii in the presence of M.phaseolina with 6.538 and $3.921 \mathrm{~g}$, respectively, and the fresh and dry weight of shoot was 3.000 and $1.144 \mathrm{~g}$, respectively. The results also indicated high significant differences in the use of $C$. globosum in increasing the fresh and dry weight of the shoot and root system, and the highest significant effect against $R$. solani for the fresh and dry weight of the root system. The result of statistical analysis indicated that there was high significant differences between $C$. globosum and M. phaseolina in increasing in the fresh and dry weight of the shoots, which was 7.085 and $2.911 \mathrm{gm}$, respectively, and increase in the dry and fresh weight of root system was 3.142 and $1.199 \mathrm{gm}$, respectively, compared to the control treatment, which recorded a fresh and dry weight of the shoot system being 4.531 and $1.959 \mathrm{~g}$, respectively, and fresh and dry weight of the root system was recorded as 3.055 and $1.222 \mathrm{gm}$, respectively. The results of the statistical analysis indicated that the use of $T$. koningii and C. globosum significantly reduced the effect of interaction between the pathogenic fungi and the low concentrations of lead and cadmium on increasing the fresh and dry weight of the vegetative and root system, and no significant differences were recorded for their interaction compared with the interaction treatments for the biofungal and pathogenic fungi.

The ability of bioagent fungi to increase the fresh and dry weight of shoot and root system may be attributed to the fact that biotic fungi help plants to overcome abiotic stress and enhance plant growth through biosynthesis of phytohormones such as Andol-3, Acetic acid, Acetic acids, Gibberellins, Cytokinins, Ethylene, Eston and 2 3Putanidol as well as nutrient absorption (He et al. 2020), Yedidia et al. (2001) reported that Trichoderma sp. can increase the phosphorus content in plants and nutrients that increase the shoot and root systems. Trichoderma sp. is a soil-borne filamentous fungi widely used for its numerous plant health benefits, such as giving their hosts improved growth, disease resistance, and abiotic stress tolerance. Several Trichoderma species are able to produce phytohormone indole-3-acetic acid (IAA), its production has been suggested to promote root growth and increase the production of chlorophyll content (Nieto-Jacobo et al. 2017).

The use of $T$. koningii against $F$. oxysprium increased the fresh and dry weight of bean seedlings, the fresh weight of root increased by 1.4 to $1.5 \mathrm{~g}$ and the dry weight of the root increased by 1.4 to $1.8 \mathrm{~g}$ (Otadoh et al. 2011). Singh et al. (2014) reported that the use of Trichoderma sp. against $R$. solani increased the fresh and dry weight of the rice plant seedlings. Inoculation of wheat with C. globosum resulted in a significant increase in plant growth and increased phosphorous content in plant tissues, increasing biomass and root length by $25 \%$ and $39 \%$, respectively (Yan et al. 2019). Murphy et al. (2019) reported that endophyte fungi such as $C$. globosum stimulate the growth of wheat and barley plants and increase the plant biomass.

Result exhibited that bioagent fungi have the ability to increase plant height in the presence of pathogenic fungi. and T. koningii achieved a significant increase of $16.2 \mathrm{~cm}$ in the presence of $R$. solani. $C$. globosum recorded a significant increase of $17.2 \mathrm{~cm}$ in the presence of the $R$. solani, and $F$. solani came to second, which scored $18.4 \mathrm{~cm}$ and did not record any significant differences between them, but they differed significantly from M.phaseolina, which achieved $20.9 \mathrm{~cm}$. The bioagent fungi reduced the negative effect of interaction between heavy metals and pathogenic fungi on wheat plant height. No significant effect was observed between the low concentrations of lead or cadmium and the pathogenic fungi in the presence of the biological fungi compared with the treatment of the biological and pathogenic fungi, and the interaction record of $R$. solani and T. koningii with $200 \mathrm{mg} / \mathrm{kg}$ of lead and 3 $\mathrm{mg} / \mathrm{kg}$ of cadmium showed an increase of 15.2 and $14.9 \mathrm{~cm}$ in height, respectively, and $R$. solani and $T$. koningii with $200 \mathrm{mg} / \mathrm{kg}$ of lead and $3 \mathrm{mg} / \mathrm{kg}$ of cadmium increased the height by 16 and $15.5 \mathrm{~cm}$, respectively (Table 2).

The role of bioagent fungi in increasing plant height can be attributed to enhancing plant growth by converting nutrients or producing plant hormones or providing iron to reduce the harmful effects of mineral pollution to plants (Rajkumar et al. 2010; Deng 2014) ). Some bioagent fungi can reduce heavy metal toxicity and improve plant growth. Wei et al. (2014) reported that mechanisms for heavy metal biogenic fungi carrying include extracellular deposition, cell wall binding, intracellular influx of heavy metal ions by intracellular linkages, cell division, and the protective role of antioxidant systems. Different types of species have been studied for the production of antibiotics, the ability to improve plant growth and development, and its efficiency as a biological control agent (Contreras-Cornejo et al. 2009). Trichoderma species have been used in the biological treatment of soil and water pollutants such as heavy metals, biological foreign substances, toxins and environmental pollutants (Siddiquee et al. 2015). 


\begin{tabular}{|c|c|c|c|c|c|}
\hline Treatments & $\begin{array}{c}\text { Fresh weight of } \\
\text { shoot }\end{array}$ & $\begin{array}{l}\text { Dry weight of } \\
\text { shoot }\end{array}$ & Fresh weight of root & $\begin{array}{l}\text { Dry weight of } \\
\text { root }\end{array}$ & Height of plant \\
\hline Control & 4.531 & 1.959 & 3.055 & 1.222 & 28.1 \\
\hline R.S. +T.gon & 5.792 & 2.790 & 2.029 & 0.637 & 16.2 \\
\hline R.S. +T.gon+Pb200 & 4.17 & 2.808 & 2.029 & 0.511 & 15.2 \\
\hline R.S. +T.gon+Pb600 & 3.711 & 1.658 & 1.051 & 0.341 & 11.4 \\
\hline R.S. +T.gon+Cd 3 & 4.518 & 2.314 & 2.046 & 0.677 & 14.9 \\
\hline R.S. +T.gon+Cd10 & 3.122 & 1.431 & 1.611 & 0.300 & 10.1 \\
\hline R.s.+ C.glob & 5.841 & 2.938 & 2.041 & 0.716 & 17.2 \\
\hline R.s. + C.glob+Pb200 & 4.629 & 2.818 & 2.088 & 635 & 16 \\
\hline R.s. + C.glob+Pb600 & 4.126 & 1.417 & 1.077 & 0.467 & 11.9 \\
\hline R.s. + C.glob+Cd3 & 5.111 & 2.800 & 2.069 & 0.627 & 15.5 \\
\hline R.s. + C.glob+Cd10 & 3.866 & 1.768 & 1.698 & 0.440 & 11.8 \\
\hline F.S. +T.gon & 5.916 & 3.222 & 2.892 & 0.900 & 18.3 \\
\hline F.S. + T.gon $+\mathrm{Pb} 200$ & 5.061 & 3.093 & 2.431 & 0.841 & 15 \\
\hline F.S. +T.gon+Pb600 & 4.500 & 2.071 & 1.823 & 504 & 14.5 \\
\hline F.S. +T.gon+Cd3 & 5.129 & 3.117 & 2.141 & 0.723 & 17 \\
\hline F.S. +T.gon+Cd10 & 4.000 & 1.900 & 1.811 & 0.523 & 13.5 \\
\hline F.s.+ C.glob & 5.914 & 3.397 & 2.922 & 1.001 & 18.4 \\
\hline F.s. + C.glob+Pb200 & 5.400 & 3.124 & 2.707 & 0.983 & 17.2 \\
\hline F.s. + C.glob+Pb600 & 4.222 & 1.674 & 1.199 & 0.563 & 15.3 \\
\hline F.s. + C.glob+Cd 3 & 5.311 & 3.078 & 2.602 & 0.857 & 17.5 \\
\hline F.s. + C.glob+Cd10 & 4.146 & 1.916 & 1.487 & 0.439 & 14.8 \\
\hline M.ph +T.gon & 6.538 & 3.921 & 3.000 & 1.144 & 20.3 \\
\hline M.ph. +T.gon+Pb200 & 6.376 & 3.900 & 2.981 & 1.000 & 15.5 \\
\hline M.ph. +T.gon+Pb600 & 5.145 & 2.866 & 1.976 & 0.911 & 16 \\
\hline M.ph. +T.gon+Cd3 & 6.000 & 3.715 & 2.509 & 0.900 & 18.3 \\
\hline M.ph +T.gon+Cd10 & 5.000 & 2.701 & 1.995 & 0.635 & 15 \\
\hline M.ph.+ C.glob & 7.085 & 3.911 & 3.142 & 1.199 & 20.9 \\
\hline M.ph. + C.glob+Pb200 & 6.511 & 3.710 & 3.000 & 1.000 & 19.6 \\
\hline M.ph + C.glob+Pb600 & 5.31 & 2.977 & 2.400 & 0.844 & 17 \\
\hline M.ph. + C.glob+Cd3 & 6.467 & 3.699 & 1.087 & 0.944 & 18.7 \\
\hline M.ph. + C.glob+Cd10 & 5.157 & 2.843 & 1.012 & 0.740 & 16.5 \\
\hline L.S.D & 1.289 & 0.393 & 0.508 & 0.292 & 2.351 \\
\hline
\end{tabular}

\section{The efficiency of bioagent fungi in reduction of seed fungal pathogens and heavy metals interaction on some biochemical parameters of wheat plants}

Results showed that bioagent fungi has the ability to reduce the negative effect of the pathogenic fungi interfering with lead and cadmium on the total phenols content of wheat leaves. No significant differences were recorded in the interaction treatments of low concentrations with pathogenic fungi. Bioagent fungi helped to reduce the negative effect of interaction between high concentrations and pathogenic fungi. The interaction of $T$. koningii with $R$. solani and lead $(600 \mathrm{mg} / \mathrm{kg})$ showed an increase in total phenols content by $9.67 \mathrm{mg} / \mathrm{g}$. Also, the fungus C.globosum raised the total phenols content to $10.34 \mathrm{mg} / \mathrm{g}$ in the presence of $600 \mathrm{mg} / \mathrm{kg}$ lead. T. koningii and C.globosum also increased the total phenols content $(9.22$ and $9.87 \mathrm{mg} / \mathrm{g}$ ) by their interaction between $R$. solani and $10 \mathrm{mg} / \mathrm{kg}$ of cadmium, which increased compared with the interaction treatment between $R$. solani and $T$. koningii without heavy metals which was recorded $15.45 \mathrm{mg} / \mathrm{g}$ as well as with the interaction treatment between $R$. solani and C. globosum without heavy metals was recorded 18.37 $\mathrm{mg} / \mathrm{g}$ (Table 3). Phenols are aromatic benzene ring compounds that contain one or more hydroxyl groups often produce by plants to protect against stress. It is difficult to overestimate the functions of phenolic compounds in plant physiology and interchange them with biotic and abiotic stress. Phenols are responsible for plant growth stages, especially in embryo biosynthesis and pigments. It also provides protection for plants, phenolic compounds secreted upon infection or in stress conditions that prevent or damage many microorganisms, and may combat some pathogens (Bhattacharya et al. 2010). The fungus Trichoderma sp. stimulates plant defenses in wheat through its by-products and the production of flavonoids, coumarins, and phenolic compounds that break the bonds of the active groups in trichothecenes (Moya 2010). Phenols are widely distributed in the plant and some occur mainly while others are synthesized in response to pathogen attack as their appearance is part of active defense (López-Bucio et al. 2015; Rao et al. 2015). Trichoderma sp. produces antioxidants and antimicrobials compounds in addition to their ability to enhance plant structural barriers that prevent disease spread (Ghassempour et al. 2011). 
Table 3. The efficiency of bioagent fungi in reduction of seed fungal pathogens and heavy metals interaction on some biochemical parameters of wheat plant

\begin{tabular}{|c|c|c|c|c|c|c|c|}
\hline Treatments & Total phenols & $\begin{array}{l}\text { Chlorophyll } \\
\text { a }\end{array}$ & $\begin{array}{l}\text { Chlorophyll } \\
\text { b }\end{array}$ & $\begin{array}{l}\text { Total } \\
\text { chlorophyll }\end{array}$ & Anthocyanins & Carotenoids & CSI \\
\hline Control & 26.475 & 30.833 & 18.404 & 16.372 & 1.06 & 9.273 & 100 \\
\hline R.S. +T.gon & 15.456 & 13.64 & 6.391 & 5.822 & 2.266 & 5.867 & 35.560 \\
\hline R.S. + T.gon $+\mathrm{Pb} 200$ & 17.851 & 12.207 & 5.899 & 5.566 & 2.542 & 5.282 & 33.997 \\
\hline R.S. +T.gon+Pb600 & 9.676 & 9.524 & 3.244 & 4.429 & 2.721 & 3.259 & 27.052 \\
\hline R.S. +T.gon+Cd 3 & 14.847 & 10.68 & 4.244 & 5.493 & 2.311 & 5.133 & 33.551 \\
\hline R.S. +T.gon+Cd10 & 9.222 & 7.37 & 2.433 & 3.923 & 2.931 & 3.351 & 23.961 \\
\hline R.s.+ C.glob & 18.372 & 14.172 & 6.861 & 6.556 & 2.625 & 6.986 & 40.043 \\
\hline R.s. + C.glob+Pb200 & 17.084 & 13.54 & 6.600 & 6.533 & 2.466 & 6.623 & 39.903 \\
\hline R.s. + C.glob+Pb600 & 10.345 & 98.888 & 4.751 & 5.122 & 2.852 & 4.395 & 31.285 \\
\hline R.s. + C.glob+Cd3 & 16.976 & 12.239 & 6.000 & 6.484 & 2.000 & 5.604 & 39.604 \\
\hline R.s. + C.glob+Cd10 & 9.874 & 7.421 & 3.512 & 4.456 & 22.073 & 3.255 & 27.217 \\
\hline F.S. +T.gon & 19.803 & 16.879 & 5.925 & 6.503 & 1.926 & 6.284 & 39.720 \\
\hline F.S. +T.gon+Pb200 & 17.101 & 15.175 & 5.000 & 6.301 & 2.246 & 5.737 & 38.486 \\
\hline F.S. +T.gon $+\mathrm{Pb} 600$ & 10.123 & 11.709 & 4.560 & 4.644 & 2.408 & 4.179 & 28.365 \\
\hline F.S. +T.gon+Cd3 & 14.314 & 14.161 & 5.167 & 5.755 & 2.111 & 5.125 & 35.151 \\
\hline F.S. +T.gon+Cd10 & 9.234 & 10.615 & 3.251 & 4.311 & 2.471 & 3.375 & 26.331 \\
\hline F.s.+ C.glob & 22.003 & 17.913 & 6.121 & 7.654 & 1.728 & 6.544 & 46.759 \\
\hline F.s. + C.glob $+\mathrm{Pb} 200$ & 21.082 & 17.412 & 5.472 & 6.553 & 2.000 & 6.000 & 40.025 \\
\hline F.s. + C.glob+Pb600 & 14.375 & 13.305 & 5.222 & 4.636 & 2.712 & 4.568 & 28.316 \\
\hline F.s. + C.glob+Cd3 & 20.83 & 16.799 & 5.665 & 6.000 & 1.800 & 5.943 & 36.647 \\
\hline F.s. + C.glob + Cd10 & 13.196 & 12.517 & 4.232 & 4.121 & 1.488 & 4.349 & 25.171 \\
\hline M.ph +T.gon & 24.865 & 22.471 & 8.888 & 7.151 & 1.878 & 6.927 & 43.678 \\
\hline M.ph. +T.gon+Pb200 & 23.817 & 21.711 & 8.71 & 7.000 & 2.522 & 6.368 & 42.755 \\
\hline M.ph. +T.gon+Pb600 & 18.983 & 16.461 & 7.088 & 6.565 & 1.898 & 3.825 & 40.098 \\
\hline M.ph. +T.gon+Cd3 & 22.815 & 21.36 & 8.919 & 6.988 & 2.000 & 4.154 & 42.682 \\
\hline M.ph +T.gon+Cd10 & 17.845 & 14.61 & 6.341 & 6.323 & 2.249 & 3.973 & 38.620 \\
\hline M.ph.+ C.glob & 25.76 & 24.072 & 9.432 & 8.802 & 1.158 & 6.852 & 53.762 \\
\hline M.ph. +C.glob+Pb200 & 24.415 & 24.033 & 9.356 & 8.765 & 2.000 & 6.751 & 53.536 \\
\hline M.ph + C.glob+Pb600 & 18.783 & 19.276 & 8.111 & 7.232 & 2.846 & 5.239 & 44.172 \\
\hline M.ph. + C.glob+Cd3 & 23.783 & 23.333 & 9.473 & 8.345 & 2.137 & 6.461 & 50.971 \\
\hline M.ph. + C.glob+Cd10 & 19.339 & 18.563 & 8.000 & 7.225 & 2.209 & 4.244 & 44.130 \\
\hline L.S.D & 2.163 & 1.548 & 1.533 & 1.583 & 1.379 & 1.910 & 2.348 \\
\hline
\end{tabular}

A high level of chlorophyll was recorded in the leaves of wheat plant due to the use of $T$. koningii and $C$. globosum. C. globosum recorded the highest significant effect against $M$. phaseolina, and the content of chlorophyll $\mathrm{a}, \mathrm{b}$, total chlorophyll and carotenoids increased to 24.072 , $9.432,8.802$ and $6.852 \mathrm{mg} / \mathrm{g}$. The anthocyanin content decreased to $1,158 \mathrm{mg} / \mathrm{g}$, and $T$. koningii increased the chlorophyll a and b content, total chlorophyll and carotenoids in the presence of $M$. phaseolina 22.471, 8.888, 7.151 and $6.927 \mathrm{mg} / \mathrm{g}$ and reduced the anthocyanin content to $1.878 \mathrm{mg} / \mathrm{g}$. The bioagent fungi recorded the least significant effect against $R$. solani, the content of chlorophyll a, b, total chlorophyll, carotenoids were $14.172,6.861,6.556$ and $6.986 \mathrm{mg} / \mathrm{g}$, and anthocyanin content was reduced to $2.625 \mathrm{mg} / \mathrm{g}$. Treatment of $C$. globosum increased chlorophyll a, b, total chlorophyll and carotenoids to $13.64,6.391,5.822$ and $5.867 \mathrm{mg} / \mathrm{g}$, respectively, and anthocyanin content decreased to 2.266 $\mathrm{mg} / \mathrm{g}$ as compared to the treatment of pathogenic fungi alone (T. koningii). The results showed an increase in the stability index of chlorophyll due to the use of biological fungi, as it increased to $53.762 \%$ in the treatment of the interaction of $C$. globosum and $M$. phaseolina. The treatment of the fungus $C$. globosum and F. solani came second, which reached $46.759 \%$. The results of the statistical analysis indicated the significant effect of biological fungi in reducing the effect of the interaction between the concentrations of lead and cadmium and pathogenic fungi, as no significant differences were recorded for the interaction between the low concentrations of lead and cadmium and pathogenic fungi, while no significant effect of bioagent fungi was observed in reducing the effect of pathogenic fungi overlapping and high concentrations of lead and cadmium in comparison with the interaction treatments between pathogenic and bioagent fungi without lead and cadmium.

Trichoderma sp. can improve the production of plant pigments which may be attributed to its ability to colonize the roots of crop plants, this leads to the regulation of genes of pigments that improve photosynthesis of plants. Plants under physiological or environmental pressures suffer losses in their ability to photosynthesize. Inflicted by photosynthetic systems and other cellular processes produced by reactive oxygen species (ROS), but Trichoderma sp. activates biochemical pathways that reduce reactive oxygen species to less harmful molecules and other mechanisms described here make plants more resistant to biotic and abiotic stresses (Harman et al. 2019). 
The fungus Trichoderma sp. stimulated the expression of two enzymes important to maintaining electron stress conditions and the NADH-dependent hydroperoxidase reductase, another enzyme involved in transporting a single carbon core unit to different biosynthesis pathways (Segarra et al. 2007). Doni et al. (2019) indicated that Trichoderma sp. stimulates many genes in the plant, including 238 genes associated with thylakoid membranes in chloroplasts and 192 genes related to photosynthesis. When attacking plant pathogens, it stimulates the formation of highly damaging reactive oxygen species ROS. These include the anion $\mathrm{O}_{2}$, the hydroxyl radical $\mathrm{OH}$, and hydrogen peroxide. They interact with proteins, fats and other plant metabolites to form free radicals that are highly damaging to cells and damage caused by free radicals to various cellular and random components, including denaturing proteins and DNA mutation and their effects are particularly harmful to cellular membranes (Nath et al. 2013). T. harzianum was able to control disease in tomatoes caused by $R$. solani, in part due to the stimulation of enzymes that inhibit (ROS) (Youssef et al. 2016). Inoculation of wheat with the fungus $T$. harzianum led to significant increases in water-soluble compounds, such as soluble sugars, soluble proteins, and proline (Zhang et al. 2019). The use of bioagent fungi T. koningii and C.globosum increased the ability of wheat plants to withstand the biological stresses of pathogenic fungi as well as the abiotic stress of lead and cadmium of fungi, which reflected positively on Various traits such as seed germination percentage, seedling death, height and freshness and vegetative weight of the shoot and root system, as well as total phenols content in leaves, plant pigments, and chlorophyll stability index.

To summary, our results reassured the severity of wheat seed decay and seedling- damping-off caused by the fungal pathogens $R$. solani; $F$. solani and $M$. phaseolina; more severity indices were observed with the interaction between above- mentioned pathogens and heavy metals treatments with lead and cadmium. All examined parameters (morphological and biochemical features) were decreased significantly compared to control (untreated) ones. Applying bioagent fungi (T. koningii and C. globosum) leads to a significant decrease of each pathogenic and heavy metal on treated wheat plants. It is noteworthy that the bioagent fungus stimulated all examined parameters in treated wheat plants including the percentage of seed germination increased, damping-off decreased, as well as the increase in plant height. It was recorded that there was an increase in fresh and dry weight of shoot and root system. The bioagent fungi had increased the total phenol content, chlorophyll a and b, total chlorophyll, carotenoids content in leaves and chlorophyll stability. The current study recommends applying both $T$. koningii and $C$. globosum in biological control of wheat seed decay and seedling damping-off disease and heavy metal bioremediation.

\section{REFERENCES}

Abass MH, Madhi QH, Matrood AA. 2021. Identity and prevalence of wheat damping-off fungal pathogens in different fields of Basrah and Maysan provinces. Bull Natl Res Cent (2021) 45:51. DOI: 10.1186/s42269-021-00506-0

Abbas A, Jiang D, Fu Y. 2017.Trichoderma spp. as antagonist of Rhizoctonia solani. J Plant Pathol Microbiol 8 (3): 1-9. DOI: 10.4172/2157-7471.1000402

Ahammed SK, Aggarwal R, Sharma S, Gupta S, Bashyal BM. 2012. Production, partial purification and characterization of extra-cellular $\beta$-1, 3-glucanase from Chaetomium globosum and its antifungal activity against Bipolaris sorokiniana causing spot blotch of wheat. J Mycol Plant Pathol 42: 146-152.

Arnon DI. 1949. Copper enzymes in isolated chloroplasts, polyphenoxidase in Beta vulgaris. Plant Physiol 24: 1-15. DOI: 10.1186/s42269-021-00506-0

Asare-Boamah NK, Hofstra G, Fletcher RA, Dumbroff EB. 1986. Triadimefon protects bean plants from water stress through its effects on abscisic acid. Plant Cell Physiol 27:383-390.

Ashwini C. 2019. A review on Chaetomium globosum is versatile weapon for various plant pathogens. J Pharmacog Phytochem 8 (2): 946-949.

Azevedo JL, Araújo WL. 2007. Diversity and applications of endophytic fungi isolated from tropical plants. In: Ganguli BN, Deshmukh SK (eds) Fungi: multifaceted microbes. CRC Press, Boca Raton.

Bamisile BS, Dash CK, Akutse KS, Keppanan R, Afolabi OG, Hussain M, Qasim M, Wang L. 2018. Prospects of endophytic fungal entomopathogens as biocontrol and plant growth-promoting agents: An insight on how artificial inoculation methods affect endophytic colonization of host plants. Microbiol Res 217: 34-50. DOI: 10.1016/j.micres.2018.08.016

Benítez T, Rincón AM, Limón, MC, Codón AC. 2004. Biocontrol mechanisms of Trichoderma strains. Int Microbiol 7: 249-260.

Bhattacharya A, Sood P, Citovsky V. 2010. The roles of plant phenolics in defence and communication during Agrobacterium and Rhizobium infection. Mol Plant Pathol 11 (5): 705-719. DOI: 10.1111/j.13643703.2010.00625.x

Central Agricultural Statistics Organization (CASO). 2019. Part Three. Iraq. [Arabic]

Chen CM, Wang JP, Liu JJ, Zhu HC, Sun B, Wang J, Zhang JW, Luo ZW, Yao GM, Xue YB, Zhang YH. 2015. Armochaetoglobins A-J: Cytochalasan alkaloids from Chaetomium globosum TW1-1, a fungus derived from the terrestrial arthropod Armadillidium vulgare. J Nat Prod 78: 1193-1201. DOI: 10.1021/np500626x

Contreras-Cornejo HA, Macías-Rodríguez L, Cortés-Penagos C, LópezBucio J. 2009. Trichoderma virens, a plant beneficial fungus, enhances biomass production and promotes lateral root growth through an auxin-dependent mechanism in Arabidopsis. Plant Physiol 149: 1579-1592. DOI: 10.1104/pp.108.130369

Demirici EE, Eken C. 2011. In vitro antagonistic activity of fungi isolated from sclerotia on potato tubers against Rhizoctonia solani. Turk J Biol 35: 457-462.

Deng ZJ, Zhang RD, Shi Y, Hu LA, Tan HM, Cao LX. 2014. Characterization of $\mathrm{Cd}-, \mathrm{Pb}-, \mathrm{Zn}$-resistant endophytic Lasiodiplodia sp. MXSF31 from metal accumulating Portulaca oleracea and its potential in promoting the growth of rape in metal-contaminated soils. Environ Sci Pollut Res 21: 2346-2357. DOI: 10.1007/s11356-0132163-2

Doni F, Fathurrahman F, Mispan MS, Suhaimi M, Yussof WMW, Uphoff N. 2019. Transcriptome profiling of rice seedlings inoculated with symbiotic fungus Trichoderma asperellum SL2. J Plant Growth Regul 38 (4): 1507-1515. DOI: 10.1007/s00344-019-09952-7

European Union (EU). 2006. Commission regulator (EC) No.1881/2006 of $19^{\text {th }}$ December 2006 setting maximum levels of certain contaminants in foodstuffs. Official Journal of the European Union L.

FAO. 2011. FAOSTAT. FAO, Rome, Italy. http://faostat.fao.org (accessed 11.03.2015).

FAO 2018. Food and Agriculture Organization of the United Nations Database Results, Geneva. 2018. http://www.fao.org/faost at/en/\#data/QC.

Fu B, Xue J, Li Z, Shi X, Jiang BH, Fang J. 2007. Chrysin inhibits expression of hypoxia-inducible factor- $1 \alpha$ through reducing hypoxiainducible factor-1 $\alpha$ stability and inhibiting its protein synthesis. Mol Cancer Ther 6 (1): 220-226. DOI: 10.1158/1535-7163.MCT-06-0526 
Ghassempour A, Mollayi S, Farzaneh M, Sharifi-Tehrani A, Aboul-Enein HY. 2011. Variation of catechin, epicatechin and their enantiomers concentrations before and after wheat cultivar-Puccinia triticina infection. Food Chem 125: 1287-1290. DOI 10.1016/j.foodchem.2010.10.028

Harman GE, Howell CR, Viterbo A, Chet I, Lorito M. 2004. Trichoderma species--opportunistic, avirulent plant symbionts. Nat Rev Microbiol 2: 43-56. DOI: 10.1038/nrmicro797

Harman GEF, Khadka RB, Uphoff N. 2019. Endophytic strains of Trichoderma increase plants photosynthetic capability. J Appl Microbiol 130: 529546. DOI: 10.1111/jam.14368

He W, Megharaj M, Wu CY, Subashchandrabose SR, Dai CC. 2020. Endophyte-assisted phytoremediation: Mechanisms and current application strategies for soil mixed pollutants. Crit Rev Biotechnol 40: 31-45. DOI: 10.1080/07388551.2019.1675582

Humberto EO, Daniel D, Luis C. 2020. Patents on endophytic fungi for agriculture and bio and phytoremediation applications. Microorganisms 8: 1237. DOI: 10.3390/microorganisms8081237

Jones RW, Pettit RE, Taber RA. 1984. Lignite and stillage: Carrier and substrate for application of fungal biocontrol agent to the soil. Phytopathol 74: 1167-1170. DOI: 10.1094/Phyto-74-1167

Kredics L, Antal Z, Manczinger L, Nagy E. 2001. Breeding of mycoparasitic Trichoderma strains for heavy metal resistance. Lett Appl Microbiol 33: 112-116. DOI: 10.1046/j.1472765x.2001.00963.x

Kredics L, Dóczi I, Antal Z, Manczinger L. 2001. Effect of heavy metals on growth and extracellular enzyme activities of mycoparasitic Trichoderma strains. Bull Environ Contam Toxicol 66 (2): 249254.DOI: $10.1007 / \mathrm{s} 001280000231$

Latz MAC, Jensen B, Collinge DB, Jørgensen HJL. 2018. Endophytic fungi as biocontrol agents: Elucidating mechanisms in disease suppression. Plant Ecol Divers 11: 555-567. DOI: 10.1080/17550874.2018.1534146

Lopez-Bucio J, Pelagio-Flores R, Herrera-Estrella A. 2015. Trichoderma as biostimulant: exploiting the multilevel properties of a plant beneficial fungus. Sci Hortic 196: 109-123. DOI: 10.1016/j.scienta.2015.08.043

Madhi QH, Abass MH, Matrood AA. 2020. Heavy metals pollution of wheat fields (soil and leaves) sampled from Basrah and Maysan provinces. Periódico Tchê Química. ISSN 2179-0302. DOI 10.52571/PTQ.v17.n35.2020.28_MADHI_pgs_315_326.pdf

Manara A. 2012. Plant responses to heavy metal toxicity. In: Furini A (eds) Plants and Heavy Metals. Springer Briefs in Biometals. Springer, Netherlands. DOI: 10.1007/978-94-007-4441-7_2

Mani R, Natesan V. 2018. Chrysin: Sources, beneficial pharmacological activities, and molecular mechanism of action. Phytochemistry 145 187-196. DOI: 10.1016/j.phytochem.2017.09.016

Mesterházy A, Judit O, József P. 2020. Losses in the Grain Supply Chain: Causes and Solutions. Sustainability 12: 2342; DOI: $10.3390 / \mathrm{su} 12062342$.

Moubarak MY, Abdel-Monaim MF. 2011. Effect of bio-control agents on yield, yield components and root rot control in two wheat cultivars at New Valley region, Egypt. J Cereals Oilseeds 2 (6): 77-87. DOI: 10. 5897/JCO11.029

Moya EA. 2010. Distribution and interaction of Fusarium crown rot and common root rot pathogens of wheat in Montana and development of an integrated management program for Fusarium crown rot. [Thesis[. Montana State Univ., USA.

Murphy B, Doohan F, Hodkinson T. 2019. Endophytes from Wild Populations of Barley Increase Crop Yield.WO 2019115582 A1, 20 June 2019.

Naeimi S, Okhovvat SM, Javan-Nikkhah M, Vágvölgyi C, Khosravi V, Kredics L. 2010. Biological control of Rhizoctonia solani AG1-1A, the causal agent of rice sheath blight with Trichoderma strains. Phytopathol Mediterr 49: 287-300.

Nandy S, Das T, Tudu CK, Pandey DK, Dey A, Ray P. 2020. Fungal endophytes: Futuristic Tool in Recent Research Area of Phytoremediation. S Afr J Bot 2020. DOI: 10.1016/j.sajb.2020.02.015

Nath K, Jajoo A, Poudyal RS, Timilsina R, Park YS, Aro E M, Nam HG, Lee CH. 2013. Towards a critical understanding of the photosystem II repair mechanism and its regulation under stress conditions.FEBS Lett 587: 3372-3381. DOI: 10.1016/j.febslet.2013.09.015

Nieto-Jacobo MF, Steyaert JM, Salazar-Badillo FB, Nguyen DV, Rostás M, Braithwaite M, De Souza JT, Jimenez-Bremont JF, Ohkura M, Stewart A, Mendoza-Mendoza A. 2017. Environmental growth conditions of Trichoderma spp. affects indole acetic acid derivatives, volatile organic compounds, and plant growth promotion. Front Plant Sci 8: 102.

Otadoh JA, Sheila A O, James O, James KP. 2011. Assessment of Trichoderma isolated for virulence efficacy on Fusarium oxysporum F. sp. Phaseoli. Trop. and Subtropical Agroecosystems 13 (2011): 99107.

Pandey PK, Samanta R,Yadav RNS. 2019.Inside the Plant: Addressing Bacterial Endophytes in Biotic Stress Alleviation. Arch Microbiol 201: 415-429. DOI: 10.1007/s00203-019-01642-y

Pischik VN, Provorov NA, Vorobyov NI, Chizevskaya EP, Safronova VI, Tuev NA, Kozhemyakov AP. 2009. Interactions between plants and associated bacteria in soils contaminated with heavy metals. Microbiology 78: 785-793. DOI: 10.1134/S0026261709060162

Rajkumar M, Ae N, Prasad MNV, Freitas H. 2010. Potential of siderophore-producing bacteria for improving heavy metal phytoextraction. Trends Biotechnol 28: 142-149. DOI: 10.1016/j.tibtech.2009.12.002

Rao GS, Reddy NNR, Surekha C. 2015. Induction of plant systemic resistance in Legumes Cajanus cajan, Vigna radiata, Vigna mungo against plant pathogens Fusarium oxysporum and Alternaria alternata - a Trichoderma viride mediated reprogramming of plant defense mechanism. Int J o Sci Res 6: 4270-4280.

Sairam RK, Shukla DS, Saxena DC. 1997. Stress induced injury and antioxidant enzymes in relation to drought tolerance in wheat genotypes. Biol Plant 40: 357-364. DOI: 10.1023/A:1001009812864

Segarra G, Casanova E, Bellido D, Odena MA, Oliveira E, Trillas I. 2007. Proteome, salicylic acid and jasmonic acid changes in cucumber plants inoculated with Trichoderma asperellum strain T34. Proteomics 7: 3943-3952. DOI: 10.1002/pmic.200700173

Siddiquee S, Rovina K, Al Azad S, Naher L, Suryani S, Chaikaew P. 2015. Heavy metal contaminants removal from wastewater using the potential filamentous fungi biomass: a review. Microbial and Biochemical Technol 7 (6): 384-93

Singh PK, Tewari RK. 2003. Cadmium toxicity induced changes in plant water relations and oxidative metabolism of Brassica juncea $\mathrm{L}$. plants. J Environ Biol 24: 107-112.

Singleton VL, Rossi JA. 1965. Colorimetry of total phenolics with phosphomolybdic phosphotungsic acid reagents. Am J Enol Vitic 16: 144-158.

Siya K, Madhuree K, Kuttuvan V, Jayabaskaran C. 2020. Endophytic fungus, Chaetomium globosum, associated with marine green alga, a new source of Chrysin. Sci Reports 10: 18726. DOI: 10.1038/s41598020-72497-3

Vinale F, Sivasithamparam K, Ghisalberti EL, Woo SL, Nigro M, Marra R, Lombardi N, Pascale A, Ruocco M, Lanzuise S, Manganiello G. 2014. Trichoderma secondary metabolites active on plants and fungal pathogens. Open Mycol J 8 (1): 127-139. DOI: 10.2174/1874437001408010127

Wei Y, Hou H, Shang Guan YX, Li JN, Li FS. 2014. Genetic diversity of endophytic bacteria of the manganese-hyperaccumulating plant Phytolacca americana growing at a manganese mine. Eur J Soil Biol 62: 15-21. DOI: 10.1016/j.ejsobi.2014.02.011

Wheeler BEJ. 1970. An introduction to plant disease. John Wiley and Sons. Ltd., London.

Wu CH, Bernard SM, Andersen GL, Chen W. 2009.Developing microbeplant interactions for applications in plant-growth promotion and disease control, production of useful compounds, remediation and carbon sequestration. Microb Biotechnol 2: 428-440.

Wu JF, Lin XG. 2003. Effects of soil microbes on plant growth. Soil 35 (1): 18-21. DOI: $10.1111 / \mathrm{j} .1751-7915.2009 .00109 . \mathrm{x}$

Yamada T, Muroga Y, Jinno M, Kajimoto T, Usami Y, Numata A, Tanaka R. 2011. New class azaphilone produced by a marine fishderived Chaetomium globosum. The stereochemistry and biological activities. Bioorg Med Chem 19 (13): 4106-4113. DOI: 10.1016/j.bmc.2011.05.008

Yan L, Zhu J, Zhao X, Shi J, Jiang C, Shao D. 2019. Beneficial, effects of endophytic fungi colonization on plants. Appl Microbiol Biotechnol 103: 3327-3340. DOI: 10.1007/s00253-019-09713-2

Yedidia I, Srivastva AK, Kapulnik Y, Chet I. 2001. Effect of Trichoderma harzianum on microelement concentrations and increased growth of cucumber plants. Plant Soil 235: 235-242. DOI: 10.1023/A: 1011990013955

Youssef SA, Tartoura KA, Abdelraouf GA. 2016. Evaluation of Trichoderma harzianum and Serratia proteamaculans effect on disease suppression, stimulation of ROS-scavenging enzymes and 
improving tomato growth infected by Rhizoctonia solani. Biol Control 100: 79-86. DOI: 10.1016/j.biocontrol.2016.06.001

Yue H, Wang M, Gong W, Zhang L. 2018. The screening and identification of the biological control fungi Chaetomium spp. against wheat common root rot. FEMS Microbiol Lett 365 (22). DOI 10.1093/femsle/fny242

Zhang S, Gan Y, Xu B. 2019. Mechanisms of the IAA and ACCdeaminase producing strain of Trichoderma longibrachiatum T6 in enhancing wheat seedling tolerance to $\mathrm{NaCl}$ stress. BMC Plant Biol 19: 22. DOI: $10.1186 / \mathrm{s} 12870-018-1618-5$

Zhu LJ, Guan DX, Luo J, Rathinasabapathi B, Ma LQ. 2014. Characterization of arsenic-resistant endophytic bacteria from hyperaccumulators Pteris vittata and Pteris multifida. Chemosphere 113: 9-16. DOI: 10.1016/j.chemosphere.2014.03.081 